\title{
Hubungan Antara Komunikasi Interpersonal Dengan Organizational Citizenship Behaviour Pada Karyawan Pt. Kemilau Permata Sawit
}

\author{
Bella Moneta, Harry Theozard Fikri \\ Fakultas Psikologi, Universitas Putra Indonesia YPTK Padang, Indonesia \\ Email: bebellmoneta98@gmail.com, harrytheozard@yahoo.com
}

\begin{abstract}
This study aims to determine the relationship between interpersonal communication with organizational citizenship behavior (OCB) on the employees of PT. Palm Gem Sheen. The independent variable in this study is interpersonal communication and the dependent variable is organizational citizenship behavior. Measuring instruments used in this research are interpersonal communication scale and organizational citizenship behavior scale. The sampling technique in this study was 98 employees of PT. Palm Gem Sheen. The validity and reliability test in this study used the Cronbach alpha technique. The results of the validity coefficient on the scale of interpersonal communication move from rix $=0.307$ to rix $=0.73$ with a reliability coefficient of $\alpha=0.930$ while on the scale of organizational citizenship behavior move from rix $=0.337$ to rix $=0.734$ with a reliability coefficient $\alpha=0.931$. Based on data analysis, obtained a correlation value of 0.324 with a significance level of 0.01 , which means accepted. This shows that there is a significant relationship between interpersonal communication with organizational citizenship behavior among employees of PT. Palm Gem Sheen. The effective contribution of interpersonal communication variables to organizational citizenship behaviour by $10 \%$
\end{abstract}

Keywords: interpersonal communication, organizational citizenship behavior, employees.

\begin{abstract}
Abstrak
Penelitian ini bertujuan untuk mengetahui hubungan antara komunikasi interpersonal dengan organizational citizenship behaviour (OCB) pada karyawan PT. Kemilau Permata Sawit. Variabel bebas dalam penelitian ini adalah komunikasi interpersoal dan variabel terikat adalah organizational citizenship behaviour. Alat ukur yang digunakan dalam penelitian ini adalah skala komunikasi interpersonal dan skala organizational citizenship behaviour. Teknik pengambilan sampel dalam penelitian ini adalah 98 orang karyawan PT. Kemilau Permata Sawit. Uji validitas dan reliabilitas pada penelitian ini menggunakan teknik alpha cronbach. Hasil koefisien validitas pada skala komunikasi interpersonal bergerak dari $\mathrm{r}_{\mathrm{ix}}=0,307$ sampai dengan $\mathrm{r}_{\mathrm{ix}}=0,73$ dengan koefisien reliabilitas sebesar $\alpha=0,930$ sedangkan pada skala organizational citizenship behaviour bergerak dari $\mathrm{r}_{\mathrm{ix}}=0,337$ sampai dengan $\mathrm{r}_{\mathrm{ix}}=0,734$ dengan koefisien reliabilitas $\alpha=0,931$. Berdasarkan anilisis data, diperoleh nilai korelasi sebesar 0,324 dengan taraf signifikan 0,01 yang berarti diterima. Hal ini menunjukan bahwa ada hubungan yang signifikan antara komunikasi interpersonal dengan organizational citizenship behaviour pada karyawan PT. Kemilau Permata Sawit. Adapun sumbangan efektif dari variabel komunikasi interpersonal terhadap organizational citizenship behaviour sebesar $10 \%$
\end{abstract}

Kata kunci : komunikasi interpersonal, organizational citizenship behaviour, karyawan.

\section{Pendahuluan}

Manusia adalah salah-satunya mahkluk yang diciptakan memiliki hakikat untuk bekerja. Manusia merupakan seorang pekerja. Homo Faber yang merupakan sebuah konsep yang menjelaskan manusia sebagai mahkluk pekerja. Pekerjaan merupakan sesuatu yang utama bagi kehidpan manusia. (Wikipedia.org). Bekerja adalah bagian sentral dalam kehidupan manusia, setiap pekerja harus ditata dalam kehidupan organisasi yang mampu mewujudkan tercapainya produktivitas kerja yang dibutuhkan organisasi, dan memperoleh kepuasan personal melalui kerjanya. (Watimena, 2011) Sumber daya manusia dan teknologi menempati posisi yang strategis dalam mewujudkan suatu perusahaan. Untuk mencapai tujuan perusahaan diperlukan kemampuan perusahaan dalam memanfaatkan seumber daya yang ada, sehingga mempunyai tingkat hasil dan daya guna yang tinggi. Wicaksono (2016). Manusia memperoleh keterikatan dengan kerja, yang menyatu dengan keberadaan manusia, dapat dikatakan bahwa manusia tidak dapat terpisahkan dari pekerjaannya. (Siregar, 2019). Sumber daya manusia kini semakin berperan besar bagi kesuksesan suatu organisasi, banyak organisasi menyadari bahwa unsur manusia dalam suatu organisasi dapat memberikan keunggulan bersaing, mereka membuat sasaran, strategi inovasi dan mencapai tujuan organisasi. Oleh karena itu, 
sumber daya manusia merupakan salah satu unsur yang paling vital bagi organisasi, bila sumber daya manusia diabaikan maka organisasi tidak akan berhasil mencapai tujuan dan sasaran yang ingin dicapai. Rachmawati (dalam Sari, 2014) Salah satunyaa adalah sumber daya manusia yang dapat memberi lebih kepada perusahaan, seperti yang dikatakan oleh, Amanda (2014) bahwa organisasi yang efektif membutuhkan karyawan yang tidak hanya menjalankan peranan tertentu saja, namun juga membutuhkan karyawan yang menjalankan tingkah laku yang berada di luar kewajiban formalnya atau melakukan extra role. Perilaku ini didalam konteks psikologi industri dan organisasi dikenal dengan istilah organisasi citizenship behaviour. Organisasi citizenship behaviour (OCB) merupakan kontribusi individu yang melebihi tuntuan peran di tempat kerja. Melibatkan beberapa perilaku meliputi perilaku tolong menolong orang lain, patuh terhadap aturan-aturan dan prosedur-prosedur di tempat kerja. Perilaku ini yang merupakan salah satu bentuk perilaku prososial, yaitu perilaku sosial yang positif, konstruktif dan bermakna membantu. Aldag dan Resckhe, (dalam Titisari, 2014) Organ (dalam Ramdhani, 2016) mengatakan bahwa OCB merupakan perilaku individu yang bebas, tidak berkaitan secara langsung atau eksplisit dengan sistem reward dan bisa meningkatkan fungsi efektif organisasi. OCB ini juga melibatkan beberapa perilaku, seperti perilaku menolong orang lain, menjadi volunteer untuk tugas-tugas ekstra, patuh terhadap aturan-aturan dan prosedur-prosedur di tempat kerja. Perilaku OCB dikenal juga sebagai kewarganegaraan organisasional yaitu perilaku yang merupakan pilihan dan inisiatif individual, tidak berkaitan langsung dengan sistem reward formal organisasi tetapi dapat meningkatkan efektivitas organisasi. Robbins (dalam Yuniar dkk, 2011) menjelaskan bahwa organisasi citizenship behaviour adalah perilaku pilihan yang bukan merupakan bagian dari persyaratan-persyaratan jabatan formal seorang karyawan. Meskipun hal itu mendorong organisasi untuk berfungsi secara efektif atas organisasi. Perilaku organisasi citzenship behaviour (OCB) dalam organisasi seperti membantu rekan kerja, sukarela melakukan kegiatan ekstra di tempat kerja, menghindari konflik dengan rekan kerja, melindungi properti organisasi, menghargai peraturan yang berlaku di dalam organisasi dan toleransi pada situasi yang kurang ideal atau tidak menyenangkan di tempat kerja, datang dengan tepat waktu, memberi saran-saran yang mebangun di tempat kerja serta tidak membuang-buang waktu di tempat kerja dengan hal yang sia-sia. Organisasi citizenship behaviour perilaku yang bukan merupakan bagian dari job description karyawan secara formal yang menguntungkaan organisasi dan tidak berkaitan dengan sistem kompensasi. Gibson (dalam Suzana, 2017) organisasi citizenship behaviour di tempat kerja sangat penting bagi keberlangsungan hidup organisasi. Organisasi citizenship behaviour dapat memaksimalkan efisiensi dan produktivitas karyawan maupun organisasi yang akhirnya memberikan kontribusi pada funsi efektif suatu organisasi. Secara garis besar terdapat dua faktor yang berpengaruh terhadap tinggi rendahnya kemunculan organisasi citizenship behaviour (OCB) para karyawan, yakni: faktor dari dalam diri individu dan faktor dari luar diri individu. Hardaningtyas (dalam Setyawanti, 2012) OCB lebih berhubungan dengan bagaimana karyawan bertindak sebagai makhluk sosial. Wujud sukarela dari anggota organisasi yang turut mendukung fungsi organisasi sehingga perilaku ini lebih bersifat altruistik yang di ekspresikan dalam bentuk tindakan nyata dengan memperlihatakan sikap tidak mementingkan diri sendiri dan memperhatikan kesejahteraan orang lain. Dengan kemampuan komunikasi yang baik dan berempati, karyawan dapat mengerti orang lain beserta lingkungannya serta bisa menyeimbangkan nilai-nilai individual yang dianutnya dengan nilai-nilai yang di percayai oleh lingkungannya, sehingga muncul perilaku sebagai good citizen. Shweta dan Srirang (2010) mengungkapkan yang mempengaruhi munculnya perilaku organisasi citizenship behaviour (OCB) dalam suatu organisasi yaitu disposisi individu dan motif individu, kohesivitas kelompok, kepemimpinan, sikap anggota (komitmen organisasi) dan komunikasi interpersonal. Moghimi (dalam Diasmoro, 2017) Pentingnya melakukan komunikasi dalam sebuah organisasi memiliki hubungan dan efek baik bagi peforma kerja. Komunikasi diantara pekerja adalah hal yang vital untuk menjalankan fungsinya dalam perusahaan, dengan kata lain supaya karyawan dapat menampilkan peforma yang baik karyawan harus memiliki hubungan baik pula dengan rekan kerja. Ali (dalam Harahap, 2017) kepuasan komunikasi interpersonal, kelompok, dan organisasi, adalah salah satu faktor yang dapat mempengaruhi organizational citizenship behaviour (OCB). Komunikasi interpersonal yang baik akan berdampak pada (OCB) yang terlihat antar karyawan, dan adanya hubungan baik antar karyawan, menerima keputusan organissasi. Herfina, dkk (dalam Harahap, 2017) komunikasi interpersonal mempengaruhi organizational citizenship behaviour (OCB). Bahwa komunikasi interpesonal merupakan penyampaian pesan atau pertukaran informasi langsung serta tatap muka antar individu 
yang menghasilkan pesan dan memberikan umpan balik sehingga informasi yang didapat dipahami dan disampaikan dengan baik. Siburian (dalam Diasmoro, 2017) komunikasi interpersonal menuntut adanya tindakan saling memberi dan menerima secara verbal berupa saran atau informasi diantara pelaku yang terlibat dalam komunikasi. Jika karyawan sudah memiliki komunikasi interpersonal yang baik dan efektif maka akan tercapai kesamaan makna yang diharapkan akan terwujudnya tindakan kolektif yang sama, sesuai, dan bersifat asosiatif. Komunikasi interpersonal diharapkan dapat membantu karyawan dalam mewujudkan perilaku kolektif yang baik yang bersifat in role ataupun extra role sebab didalam organisasi tidak akan lepas dari bagaiman sumber daya manusia yang bekerja didalamnya. Komunikasi juga merupakan sarana memodifikasi perilaku, mempengaruhi perubahan, memproduktifkan informasi, dan sarana untuk mencapai tujuan. Hardjana (dalam Sari dan Widodo, 2015) dengan komunikasi interpersonal karyawan mampu menjalin hubungan baik dengan rekan kerja, membangun kerja sama dan sinergi dengan rekan kerja, menginformasikan tugas dan mengarahkan kinerja agar sesuai dengan tujuan serta mengatasi perbedaan pendapat, ketegangan dan konflik di tempat kerja. Dalam menjalankan sebuah organisasi diperlukan sikap dari para anggota agar dapat mencapai tujuan bersama. Namun masih banyak tantangan untuk membangun komunikasi. Pertama, kurangnya pengertian setiap anggota mengenai sebuah komunikasi dan bagaimana seharusnya mereka bekerja dalam organisasi. Kedua, sikap egois yang masih muncul di kalangan anggota, urusan pribadi sering dicampur adukan dengan tanggung jawabnya dalam organiasi.

\subsection{Organizational citizenship behaviour}

Organizational citzenship behaviour (OCB) merupakan perilaku inisiatif individu, yang tidak berkaitan dengan sistem reward formal organisasi tetapi dapat meningkatkan efektivitas organisasi. Yang berarti perilaku tersebut tidak termasuk dalam persyaratan kerja atau deskripsi kerja karyawan sehingga jika tidak ditampilkan tidak akan diberi hukuman. Organ (dalam Titisari, 2014). Organizational citizenship behaviour (OCB) dapat melancarkan kehidupan sosial dalam suatu organisasi. Smith (dalam Titisari, 2014). Organisasi citizenship behaviour (OCB) merupakan kontribusi individu yang melebihi tuntuan peran di tempat kerja. Melibatkan beberapa perilaku meliputi perilaku tolong menolong orang lain, patuh terhadap aturan-aturan dan prosedur-prosedur di tempat kerja. Perilaku ini yang merupakan salah satu bentuk perilaku prososial, yaitu perilaku sosial yang positif, konstruktif dan bermakna membantu. Aldag dan Resckhe (dalam Titisari, 2014)

\subsection{Dimensi organizational citizenship behaviour}

Menurut Menurut Organ (dalam Titisari, 2014) dimensi Organisasi Citizenship Behaviour (OCB) sebagai berikut:(a) altruism, menerangkan tentang perilaku karyawan dalam menolong karyawan yang lain (b) conscientiousness, berkenaan dengan perilaku yang ditunjukan dengan berusaha melebihi apa yang diharapkan perusahaan (c) sportmanship, menerangkan perilaku yang memberikan toleransi yang tidak sesuai dengan aturan perusahaan dalam suatu organisasi (d) courtessy, menerangkan akan perilaku menjaga hubungan baik dengan rekan kerja agar terhindar dari masalah-masalah interpersonal (e) civic virtue, merupakan perilaku yang mengidentifikasi perilaku yang tanggung jawab pada kehidupan organisasi.

\subsection{Komunikasi interpersonal}

Trenholm dan Jensen (dalam Suranto, 2011) mendefinisikan komunikasi interpersonal sebagai komunikasi antara dua orang yang berlangsung secara tatap muka. Littlejohn (dalam Suranto, 2011) mendefinisikan komunikasi interpersonal sebagai komunikasi antar individu-individu. Hardjana (dalam Suranto, 2011) komunikasi interpersonal merupakan interaksi tatap muka antara dua atau beberapa orang, dimana pengirim dapat menyampaikan pesan secara langsung dan penerima dapat menerima, menanggapi secara langsung. Mulyana (dalam Suranto, 2011) komunikasi interpersonal adalah komunikasi antara orang-orang secara tatap muka, yang memungkinkan setiap pesertanya menangkap reaksi orang lain secara langsung, baik secara verbal maupun non verbal. 


\subsection{Aspek-Aspek Komunikais Interpersonal}

Aspek-aspek komunikasi interpersonal menurut De Vito (dalam Suranto, 2011) mengemukakan lima aspek komunikasi interpersonal yaitu: (a) keterbukaan, merupakan sikap dapat menerima masukan dari orang lain (b) empati terhadap karyawan, merupakan kemampuan seseorang untuk merasakan, memahami sesuatu yang sedang dirasakan atau yang sedang dialami orang lain (c) sikap mendukung, sikap dimana masing-masing pihak yang berkomunikasi memiliki komitmen untuk mendukung terselenggaranya interaksi (d) sikap positif, adalah pihak-pihak yang terlibat dalam komunikasi interpersonal harus memiliki perasaan dan pikiran yang posisitf, bukan prasangka dan curiga (e) kesetaraan, adalah pengakuan bahwa kedua belah pihak memiliki kepentingan, sama-sama bernilai dan berharga serta saling memerlukan.

\section{Metode Penelitian}

Jenis penelitian ini adalah kuantitatif korelasional dengan variabel penelitian Menurut Sugiyono (2014) variabel Dependen, penelitian Organizational Citizenship Behaviour (Y) dan Variabel Independen, Komunikasi Interpersonal (X). Populasi pada penelitian ini adalah seluruh karyawan PT. Kemilau Permata Sawit yang berjumlah 98 orang. Teknik pengambilan sampel dalam penelitian ini adalah sampling jenuh yaitu teknik penentuan sampel bila semua anggota populasi digunakan sebagai sampel. Alat ukur yang digunakan dalam penelitian ini adalah skala Komunikasi Interpersonal dan Organizational Citizenship Behaviour. Menurut Azwar (2017) skala merupakan perangkat pertanyaan yang disusun untuk mengungkap atribut tertentu melalui respon terhadap pertanyaan tersebut. Skala dalam penelitian ini memiliki format respon dengan empat alternatif jawaban. Skala yang digunakan dalam penelitian ini menggunakan format respon jawaban model Likert, yaitu suatu metode pernyataan sikap yang menggunakan respon subjek sebagai penentu nilai skalanya yang telah dimodifikasi menjadi empat alternatif jawaban dan aitem-aitem dalam skala ini dikelompokkan dalam aitem favorable dan unfavorable. Bentuk skala yang digunakan untuk mengukur intensi prososial dan skala kepuasan pengguna menggunakan empat alternatif jawaban, yaitu SS (Sangat Setuju), S (Setuju), TS (Tidak Setuju), dan STS (Sangat Tidak Setuju). Skala penelitian akan melewati berbagai tahap analisis yaitu uji normalitas digunakan untuk mengetahui apakah populasi data terdistribusi normal atau tidak. Uji normalitas menggunakan uji kolmogorov-Smirnov. Uji linearitas bertujuan untuk mengetahui apakah dua variabel mempunyai hubungan yang linear atau tidak. Dua variabel dikatakan mempunyai hubungan yang linear bila signifikasi (linearty) kurang dari 0,05.

Selain itu dilakukan uji Validitas, sejauh mana ketepatan dan kecermatan suatu alat ukur dalam melakukan fungsi ukurnya (Azwar, 2017). Suatu item dapat dianggap memiliki daya diskriminasi yang memuaskan jika berkorelasi signifikan terhadap skor total atau jika melakukan penilaian langsung terhadap koefisien korelasi bisa digunakan batas nilai berkriteria rxy $\geq 0,3$ (Priyatno, 2018). Data skala dikatakan memiliki daya beda tinggi jika koefisien korelasi lebih besar atau sama dengan 0,3 (rxy $\geq 0,3$ ) dan sebaliknya aitem skala dikatakan gugur jika koefisien korelasi lebih kecil dari 0,3 $(\mathrm{rxy} \geq 0,3)$.

\section{Hasil dan Pembahasan}

Peneliti menyebarkan 98 skala Komunikasi Interpersonal dan Organizational Citizenship Behaviour dan meminta kesediaan kepada karyawan tersebut untuk mengisi skala kemudian menjelaskan cara pengisian skala dengan cara memberikan skala secara langsung kepada karyawan PT. Kemilau Permata Sawit. Sebelum pengisian skala dilakukan, peneliti terlebih dahulu memberitahukan petunjuk pengisian dengan singkat dan jelas.

\subsection{Hasil}

Koefisien Validitas skala Komunikasi Interpersonal dengan nilai corrected item-total correlation berkisar antara 0,307 sampai dengan 0,731, dengan reabilitas 0,930 , validitas skala organizational citizenship behaviour dengan nilai corrected item-total correlation berkisar antara 0,337 sampai dengan 0,734, dengan reabilitas 0,931 . Uji normalitas dalam penelitian ini menggunakan uji Kolmogorov-Smirnov. Priyatno (2018) menyatakan bahwa data yang dinyatakan berdistribusi normal jika signifikansi (p) lebih besar dari 0,05. Berdasarkan hasil pengolahan data dengan menggunakan program IBM SPSS 21.0, Maka diperoleh hasil sebagai berikut: 
Bella Moneta, Harry Theozard Fikri

Psyche 165 Journal Vol 13 No 2 (2020) 176-182

Tabel 1. Uji Normalitas Skala Komunikasi Interpersonal dengan Organizational Citizenship Behaviour

\begin{tabular}{ccccc}
\hline Variabel & N & KSZ & P & Sebaran \\
\hline $\begin{array}{c}\text { Komunikasi Interpersonal } \\
\begin{array}{c}\text { Organizational Citizenship } \\
\text { Behaviour }\end{array}\end{array}$ & 98 & 1,207 & 0,108 & Normal \\
\hline
\end{tabular}

Nilai signifikansi pada skala Komunikasi Interpersonal sebesar $p=0,108$ dengan KSZ $=1,207$ hasil tersebut menunjukan bahwa nilai $p>0,05$, artinya sebaran skala Komunikasi Interpersonal terdistribusi secara normal, sedangkan untuk skala Organizational Citizenship Behaviour diperoleh nilai signifikansi sebesar $\mathrm{p}=0,127$ dengan $\mathrm{KSZ}=1,174$ hasil tersebut menunjukan bahwa nilai $\mathrm{p}$ > 0,05 , artinya sebaran terdistribusi secara normal. Selanjutnya uji linearitas dapat dilihat pada tabel 2 berikut:

Tabel 2. Uji Linieritas Komunikasi Interpersonal dengan Organizational Citizenship Behaviour

\begin{tabular}{ccccc}
\hline $\mathbf{N}$ & Df & Mean Square & F & Sig \\
\hline 98 & 1 & 669,889 & 11,576 & 0,001 \\
\hline
\end{tabular}

Berdasarkan tabel diatas, diperoleh nilai $\mathrm{F}=11,576$ dengan signifikansi sebesar $\mathrm{p}=0,001$ dengan ketentuan $(\mathrm{p}<0,05)$, artinya varian pada skala Komunikasi Interpersonal dan Organizational Citizenship Behaviour tergolong linier.

Tabel 3. Hasil Uji Korelasi Antara Komunikasi Interpersonal dengan Organizational Citizenship Behaviour

\begin{tabular}{ccccc}
\hline $\mathbf{P}$ & $(\boldsymbol{\alpha})$ & Nilai Korelasi $(\mathbf{r})$ & R square & Kesimpulan \\
\hline 0,001 & 0.01 & 0,324 & 0,105 & $\begin{array}{c}\text { sig (2-tailed) } 0,001<0,01 \text { level of } \\
\text { significant }(\alpha), \text { berarti hipotesis } \\
\text { diterima. }\end{array}$ \\
\hline
\end{tabular}

Berdasarkan tabel di atas, maka diperoleh koefisien korelasi antara variable komunikasi interpersonal dan organizational citizenship behaviour (OCB) dengan jumlah sampel penelitian sebanyak 98 karyawan, maka diperoleh nilai koefisien (r) sebesar $r_{x y}=0,324$ dengan taraf signifikansi $p=0,001$. Hal ini menunjukan bahwa terdapat hubungan yang positif antara komunikasi interpersonal dengan organizational citizenship behaviour (OCB) pada karyawan PT. Kemilau Permata Sawit.

Tabel 4. Descriptive Statistic

\begin{tabular}{cccccc}
\hline Variabel & $\mathbf{N}$ & Mean & Std. Deviation & Minimum & Maximum \\
\hline $\begin{array}{c}\text { Komunikasi } \\
\text { Interpersonal }\end{array}$ & 98 & 99,18 & 14,021 & 60 & 124 \\
$\begin{array}{c}\text { Organizational } \\
\text { Citizaship Behaviour }\end{array}$ & 98 & 86,66 & 8,101 & 75 & 111 \\
\hline
\end{tabular}

Berdasarkan nilai mean hipotetik, maka dapat dilakukan pengelompokkan yang mengacu pada kriteria pengkategorisasian dengan tujuan menempatkan individu kedalam kelompok-kelompok yang terpisah secara berjenjang menurut suatu kontinum berdasarkan atribut yang diukur (Azwar, 2017) berdasarkan norma kategorisasi, diperoleh kategorisasi subjek penelitian pada variabel, Komunikasi Interpersonal Dan Organizational Citizenship Behaviour sebagai berikut :

Tabel 5. Kategori Komunikasi Interpersonal dengan Organizational Citizenship Behaviour

\begin{tabular}{ccccc}
\hline Variabel & Skor & Jumlah & Persentase (\%) & Kategori \\
\hline Komunikasi & $60-85$ & 26 & $26,53 \%$ & Rendah \\
Interpersonal & $86-113$ & 61 & $62,24 \%$ & Sedang \\
& $114-123$ & 11 & $11,22 \%$ & Tinggi \\
Organizational & $75-78$ & 17 & $17,34 \%$ & Rendah \\
Citizenship Behaviour & $79-94$ & 64 & $65,30 \%$ & Sedang \\
& $95-111$ & 17 & $17,34 \%$ & Tinggi \\
\hline
\end{tabular}


Berdasarkan tabel diatas, maka dapat diperoleh gambaran bahwa 26,53\% komunikasi interpersonal pada kategori rendah, 62,24\% komunikasi interpersonal pada kategori sedang, dan 11,22\% komunikasi interpersonal pada kategori tinggi, sedangkan untuk variabel organizational citizenship behaviour (OCB) diperoleh gamabaran bahwa sebesar 17,34\% karyawan memiliki kinerja dengan kategori rendah, 65,30\% karyawan memiliki kinerja dengan kategori sedang, dan 17,34\% karyawan memiliki kinerja dengan tinggi. Besar sumbangan variabel Komunikasi Interpersonal terhadap variable Organizational Citizenship Behaviour dapat ditentukan dengan menggunakan rumus koefisien determinan. Koefisien determinan adalah kuadrat dari koefisien korelasi yang dikali dengan $100 \%$. Adapun besar sumbangan efektif ( $R$ square) dari variabel Komunikasi Interpersonal terhadap Organizational Citizenship Behaviour adalah sebesar 10\% artinya Komunikasi Interpersonal memiliki sumbangan sebesar 10\% Organizational Citizenship Behaviour sedangkan 90\% dipengaruhi oleh faktor lain seperti faktor internal kepuasan kerja, komitmen organisasi, kepribdian, motivasi, dan faktor eksternal seperti gaya kepemimpinan, kepercayaan pada pimpinan, dan budaya organisasi.

\subsection{Pembahasan}

Berdasarkan hasil uji korelasi Product Moment (Pearson) yang dilakukan dengan bantuan IBM SPSS 21.0, dimana level of significant $(\alpha) 0,01$ dan diperoleh nilai koefisien korelasi $\left(\mathrm{r}_{\mathrm{xy}}\right)=0,324$ dengan nilai (p) sig $=0,001$, karena nilai (p) sig 0,001<0,01 maka hipotesis diterima. Hasil ini menunjukkan bahwa terdapat hubungan antara Komunikasi Interpersonal dengan Organizational Citizenship Behaviour pada karyawan PT. Kemilau Permata Sawit dengan arah positif. Artinya jika Komunikasi Interpersonal tinggi, maka Organizational Citizenship Behaviour pada Karyawan PT. Kemilau Permata Sawit juga akan tinggi, sebaliknya jika Komunikasi Interpersonal rendah, maka Organizational Citizenship Behaviour PT. Kemilau Permata Sawit juga akan semakin rendah. Kondisi ini sesuai dengan yang dikemukakan oleh Ali (dalam Harahap, 2017) menyebutkan bahwa kepuasan komunikasi interpersonal, kelompok, dan organisasi, adalah salah satu faktor yang dapat mempengaruhi organizational citizenship behaviour (OCB). Komunikasi interpersonal yang baik akan berdampak pada (OCB) yang terlihat antar karyawan, dan adanya hubungan baik antar karyawan, menerima keputusan organissasi. Adapun menurut Siburian (dalam Diasmoro, 2017) komunikasi interpersonal dapat membantu karyawan dalam mewujudkan perilaku kolektif yang baik yang bersifat in role ataupun extra role sebab didalam organisasi tidak akan lepas dari bagaiman sumber daya manusia yang bekerja didalamnya. Komunikasi juga merupakan sarana memodifikasi perilaku, mempengaruhi perubahan, memproduktifkan informasi, dan sarana untuk mencapai tujuan. Serta Shweta dan Srirang (2010) juga mengungkapkan bahwa yang mempengaruhi munculnya perilaku organisasi citizenship behaviour (OCB) dalam suatu organisasi yaitu disposisi individu dan motif individu, kohesivitas kelompok, kepemimpinan, sikap anggota (komitmen organisasi) dan komunikasi interpersonal Berdasarkan hasil pengolahan data mengenai sumbangan efektif komunikasi interpersonal terhadap organizational citizenship behaviour (OCB), maka diperoleh nilai sumbangan efektif $(\mathrm{KP})=10 \%$ dan sisa nya sebesar $90 \%$ dipengaruhi oleh faktor lain. Adapun faktor lain yang dapat meningkatkan perilaku organizational citizenship behaviour (OCB) yaitu faktor internal seperti kepuasan kerja, komitmen organisasi, kepribadian, motivasi serta moral karyawan dan faktor ekternal seperti gaya kepemimpinan, kepercayaan pada pimpinan atau rekan kerja dan budaya organisasi. Siders (dalam Titisari, 2014)

\section{Kesimpulan}

Berdasarkan hasil analisis data yang telah dilakukan oleh peneliti, maka dapat ditarik kesimpulan yang sekaligus merupakan jawaban dari tujuan penelitian adalah sebagai berikut : terdapat hubungan yang signifikan antara Komunikasi Interpersonal dengan Organizational Citizenship Behaviour pada Karyawan PT. Kemilau Permata Sawit. Hubungan antara kedua variabel tersebut positif yang artinya semakin tinggi Komunikasi Interpersonal maka semakin tinggi Organizational Citizenship Behaviour dan sebaliknya semakin rendah Komunikasi Interpersonal maka semakin rendah Organizational Citizenship Behaviour, hal ini berarti hipotesis diterima.

\section{Daftar Rujukan}


Amanda, Agustiani Rifania. (2014). Pengaruh Employee Communication Terhadap Organizational Citizenship Behaviour yang dimediasi oleh Employee Engagement pada Karyawan dibeberapa Fakultas Universitas Tri Sakti Jakarta. Jurnal Manajemen dan Pemasaran Jasa. Volume 7, No.1.

Azwar, Saifuddin. (2017). Metode Penelitian Psikologi. Yogyakarta : Pustaka Pelajar

DeVito, Joseph A. (2011). Komunikasi Antar Manusia Edisi Kelima. Karisma Publishing Group. PamulangTanggerang Selatan.

Diasmoro, Okky. (2017). Hubungan kKomunikasi Interprsonl dengn Kepuasan Kerja aryawan Dewsa Awal Bagian Produksi PT. Gangsar Tulunggung. Jurnal Ilmiah Psikologi Terapan. Volume5, No.1

Harahap, Fitriani (2017). Komunikasi Interpersonal guru di SMK Negeri 1 angkola Timur. Jurnal Pendidikan STKIP. Tapanuli Selatan.

http://id.m.wikipedia.org/wiki/Homo_faber

Laksna, Muhibudin Wijaya. (2015). Psikologi Komunikasi. CV. Pusta Setia. Jawa Barat-Bandung.

Prayitno, Duwi. (2018). SPSS Panduan Mudah Olah Data Bagi Mahasiswa \& Umum. Andi: Yogyakarta.

Ramdhani Bayu Putra. (2016). Efek Mediasi Kepuasan Kerja Terhadap Kinerja Dengan Komitmen Organisasi, Komunikasi Interpersonal dan organizational Citizenship Behaviour (OCB) sebagai variabel anteseden. Jurnal Praktik Bisnis Fakultas Ekonomi. Universitas Putra Indonesia YPTK Padang.

Rahmat, Jalaludin. (2011). Psikologi Komunikasi. PT. Remaja Rosdakarya. Bandung.

Rahmawati, Tri dan Arik Prasetya. (2017). Analisis Faktor-Faktor yang mempengaruhi Organizatinal Citizenship Behaviour (OCB) Pada Karyawan Tetap dan Karyawan Kontrak (Studi Kasus Karyawan Pizza Hut Kota Malang). Jurnal Adminitrasi Bisnis. Volume 48, No.1.

Sari, Yuanita Widyanti Sofiana. (2014). Pengaruh Komunikasi Internal, Reward dan Punsihment terhadap Motivasi Kerja Karyawan Di BPR Nur Semesta Indah Kencong Kabupaten Jember. Jurnal Ekonomi Dan Bisnis.

Sari, Selsia Kartika dan Widodo, Prasetyo Budi. (2015). Komunikasi Interpersonal Antar Karyawan Dan Motivasi Kerja Pada Karyawan PT Bank Negara Indonesia (PERSERO) Tbk Kantor Wilayah Semarang. Jurnal Empati. Volume 4, No.4.

Setyawanti, Erna. (2012). Pengaruh Tingkat Kecerdasan emosi dan Sikap Budaya Organisasi Terhadap Organizational Citizenship Behaviour (OCB) Pegawai PT PLN (PERSERO) Area Pelayanan dan Jaringan (APJ) Purwokerto. Jurnal Probisnis. Volume 5, No.2.

Shweta, Jha dan Srirang Jha. (2010). Determinant of Organizational Citizenship Behaviour (OCB) : A Review of literature. Journal of Management \& Public Policy. Volume 1, No.2.

Siregar, Hunter Oriko. (2019). https: //www.kompasiana.com/hanter76061/ mengapa-kita-harus-bekerja

Sugiyono. (2014) Metode Penelitian Kuantitatif dan Kualitatif. Alfabeta. Bandung.

Suranto AW. (2011). Komunikasi Interpersonal. Graha Ilmu. Yogyakarta.

Suzana, Anna. (2017). Pengaruh Organizational Citizenship Behaviour (OCB) Terhadap Kinerja Karyawan. Jurnal Logika. Volume XIX, No.1.

Titisari, Purnamie. (2014). Peranan Organizational Citizenship Behaviour (OCB) dalam Meningkatkan kinerja karyawan. Mitra Wacana Media. Jember.

Wattimena, Reza a.a (2011). https://rumahfilsafat.com/2011/03/07/makna-kerja-dalam-hidup-manusia

Wicaksono, Yosep Putra. (2016). Pengaruh Pelatihan Dan Pengembangan Sumber Daya Manusia Dalam rangka Meningkatkan Semangat Kerja Dan Kinerja Karyawan (Studi di SKM Unit V PT. Gudang Garam, Tbk Kediri). Jurnal Bisnis dan Manajemen. Volume 3, No.1.

Wiwik, dkk. (2012). Hubungan Antara Kecerdasan emosional dengan Organiztional Citizenship Behaviour (OCB) pada karyawan CV. Aneka Ilmu Semarang. Jurnal Psikologi UNDIP.

Yuniar, I GustiAyu A. Y, Harlina N. Diana R. (2011). Hubungan Antara KepuasannKerja dan Resiliensi dengan Organizational Citizenship Behaviour (OCB) Pada Karyawan Kantor Pusat PT BPD Bali. Jurnal Psikologi. Volume 9, No.1.

Zulhafni. (2011). Hubungan Antara Iklim Organisasi dan Komunikasi Interpersonal Dengan Perilaku Agresif Pada Anggota Satuan Reserse kriminal Polda Sumatera Utara. Jurnal Analitika.

Kurniawan, H. (2019). HUBUNGAN ANTARA KONFLIK PERAN DAN AMBIGUITAS PERAN DENGAN KINERJA PERAWAT WANITA DI RSUD SUNGAI DAREH DHARMASRAYA. Psyche 165 Journal, 12(2), 124-133. 